\title{
'Smashed by the National Health'? A Closer Look at the Demise of the Pioneer Health Centre, Peckham
}

\author{
PHILIP CONFORD * \\ School of Historical Studies, University of Leicester, University Road, \\ Leicester LE1 7RH, UK
}

\begin{abstract}
The Pioneer Health Centre, based in South London before and after the Second World War, remains a source of interest for advocates of a positive approach to health promotion in contrast with the treatment of those already ill. Its closure in 1950 for lack of funds has been blamed on the then recently established National Health Service, but this article argues that such an explanation is over-simplified and ignores a number of other factors. The Centre had struggled financially during the 1930s and tried to gain support from the Medical Research Council. The Council appeared interested in the Centre before the war, but was less sympathetic in the 1940s. Around the time of its closure and afterwards, the Centre was also involved in negotiations with London County Council; these failed because the Centre's directors would not accept the changes which the Council would have needed to make. Unpublished documents reveal that the Centre's directors were uncompromising and that their approach to the situation antagonised their colleagues. Changes in medical science also worked against the Centre. The success of sulphonamide drugs appeared to render preventive medicine less significant, while the development of statistical techniques cast doubt on the Centre's experimental methods. The Centre was at the heart of the nascent organic farming movement, which opposed the rapid growth of chemical cultivation. But what might be termed "chemical triumphalism' was on the march in both medicine and agriculture, and the Centre was out of tune with the mood of the times.
\end{abstract}

Keywords: Pioneer Health Centre, National Health Service, Medical Research Council, London County Council, George Scott Williamson, Chemical triumphalism

\section{Introduction}

Although it closed its doors in 1950, the Pioneer Health Centre (PHC) in Peckham, South London (also known as the Peckham Health Centre or the Peckham Experiment) remains a project whose significance and legacy are vigorously contested. On the one hand, there

* Email address for correspondence: paconford@aol.com

The author is grateful to Dr Peter Mansfield and the Saville Turner Holistic Trust for funding which enabled him to undertake the research for this article. He also thanks the three anonymous referees who offered guidance and comments. 
are those who have criticised what they see as its over-ambitious and ill-defined aims; its lack of scientific and statistical rigour; its sinister extension of the 'medical gaze' and its essentially conservative conception of the family. ${ }^{1}$ On the other, there are those who regard the National Health Service (NHS) as more accurately a 'sickness service', and seek to establish initiatives actively promoting health rather than attending only to people already unwell. In particular, the Pioneer Health Foundation (PHF) keeps the Peckham flame burning, with some success. The PHC's founders, Dr George Scott Williamson (1884-1953) and Dr Innes H. Pearse (1889-1978), were hostile to the NHS, but there are doctors active in the PHF who work in the NHS and believe that the Service would benefit from a re-consideration of the Peckham approach. ${ }^{2}$

This article's chief purpose is to examine the circumstances surrounding the PHC's closure, and the reasons for it, and to assess which organisations and individuals might be held responsible for that event. However, a brief summary of the Centre's history, principles and practice is necessary. ${ }^{3}$ Its first incarnation, from 1926 to 1929, was a response to widespread concern about the fitness of the British people. In effect an exercise in positive eugenics, it aimed to encourage the health of the fit rather than 'working to reverse the Law of Nature by procuring the survival of the unfit'. ${ }^{4}$ In 1925 Scott Williamson was Director of Pathological Studies at the London School of Medicine for Women, specialising, with his colleague Innes Pearse, in thyroid research. Despite their professional commitment to pathology, Scott Williamson and Pearse believed that medical scientists were wrong to ignore "the uncomplaining or so-called "healthy", members of the population. If the nation's health was to be improved, focusing on disease was unlikely to provide the clue to how this might be achieved; similarly, Scott Williamson and Pearse were sceptical about the scientific validity of the methods which geneticists advocated. They envisaged instead an experiment in social biology, in order 'to explore

\footnotetext{
1 The epidemiologist Dr Julian Tudor Hart believed that 'Far too much was attempted' at the PHC, and that the Peckham doctors tended 'to leap far ahead of the real scientific knowledge then available'. Letter to Dr Peter Mansfield, 30 April 1980; in author's possession. On the 'medical gaze' see David Armstrong, n. 8 below. On the PHC's attitude to the family, see Pyrs Gruffudd, "Science and the Stuff of Life": Modernist Health Centres in 1930s London', Journal of Historical Geography, 27, 3 (2001), 402-3.

${ }^{2}$ For example, Dr Margaret Hannah, Deputy Director of Public Health in NHS Fife, is a PHF Trustee. Her book Humanising Health Care (Axminster: Triarchy Press, 2014) is endorsed by Iona Heath, former President of the Royal College of General Practitioners, and Professor Patrick Maxwell, Head of the School of Clinical Medicine at the University of Cambridge. Dr Jack Czauderna, PHF Chair, was for many years a Sheffield GP. Interviews with Dr Hannah (28 April 2015) and Dr Czauderna (13 October 2014).

${ }^{3}$ For a full account of the Centre's origins and achievements, readers are referred to the various publications of those who initiated it and those who worked there, and to the articles which Jane Lewis and Barbara Brookes wrote in the 1980s, based on their study of the Centre's archival material. Lesley Hall, archivist at the Wellcome Library, where most of the Centre's papers are lodged, has provided an essential overview of what they contain. Writings by those with first-hand experience of the Pioneer Health Centre include Innes H. Pearse and G. Scott Williamson, The Case for Action (London: Faber and Faber, 1931); G. Scott Williamson and I.H. Pearse, Biologists in Search of Material (London: Faber and Faber, 1938); Innes H. Pearse and Lucy H. Crocker, The Peckham Experiment (London: Allen and Unwin, 1943); G. Scott Williamson, Physician, Heal Thyself (London: Faber and Faber, 1945); G. Scott Williamson and Innes H. Pearse, Science, Synthesis and Sanity (London: Collins, 1965); Innes H. Pearse, The Quality of Life (Edinburgh: Scottish Academic Press, 1979); Kenneth Barlow, Recognising Health (London: Kenneth Barlow, 1988), and Alison Stallibrass, Being Me and Also Us (Edinburgh: Scottish Academic Press, 1989). Jane Lewis and Barbara Brookes, 'The Peckham Health Centre, "PEP", and the Concept of General Practice during the 1930s and 1940s', Medical History, 27 (1983), 151-61; and 'A Reassessment of the Work of the Peckham Health Centre, 1926-1951', Health and Society, 61, 2 (1983), 307-50. Lesley A. Hall, 'The Archives of the Pioneer Health Centre, Peckham, in the Wellcome Library', Social History of Medicine, 14, 3 (2001), 525-38.

${ }^{4}$ Innes H. Pearse and G. Scott Williamson, The Case for Action (London: Faber and Faber, 1938), 3.
} 
the environmental factor in inheritance', and with a small group of non-medical associates opened in April 1926 a family club at 142 Queens Road, Peckham. They chose this area because its population was chiefly 'of good artisan type, but including as wide an admixture of cultural types as it is possible to find within any small area in the metropolis', unaffected by long-term unemployment or serious social problems. ${ }^{5}$

The Centre's staff consisted of a resident medical officer, a social secretary and a housekeeper, while the facilities included a changing room, a consulting room, a bathroom and a club-room. Membership was for families only, and in return for a small weekly sum they received periodic medical and dental examinations, a parents' clinic, an orthopaedic clinic, and ante- and post-natal clinics. There was also a children's afternoon nursery. The Centre's service was purely advisory, its aim being to identify the early stages of disease and 'to evoke a desire for health'. During the Centre's three years in Queens Road, 112 families joined, and the doctors concluded that there were many families who, in the right circumstances, would welcome a service which encouraged health rather than dealing with sickness. ${ }^{6}$

Scott Williamson and Pearse therefore closed the first stage of the Centre and spent the next six years planning and raising funds for the second, which required an environment providing families with an outlet for all their members. Sufficient money was obtained, mainly from private individuals, to begin the project, and the Pioneer Health Centre building, designed by the noted architectural engineer Sir Owen Williams, opened in 1935 in St Mary's Road, Peckham. It contained a swimming-pool, separated only by glass from the rooms surrounding it; a gymnasium, dance hall and cafeteria, all similarly visible; a billiard room; a small theatre; a pool for babies; nurseries and a children's playground. There were also medical consulting rooms and a laboratory. The Centre's staff did not run the leisure activities; it was the members who discovered what they wanted to do and then organised it. After an initial period of chaos, a spontaneous order emerged which combined a feeling of heightened individuality with strong communal integration, giving many members a lifelong spirit of confidence. ${ }^{7}$

The doctors had two main roles: observing members' activities and providing an annual medical overhaul for each family member. Acceptance of this overhaul was a necessary condition of membership, which was for families only and required payment of a token fee for use of the Centre and for its various activities. The doctors shared with the parents information gleaned via the overhaul, and offered advice about conception, pregnancy and post-natal matters. No treatment was provided: parents were left to decide what action they should take.

Scott Williamson and Pearse saw themselves more as biologists than as doctors, and from their biologists' perspective the family was the basic social unit. By creating the best conditions possible for the development of body, mind and spirit they hoped to discover how health could be encouraged, and to see if any laws of healthy development revealed themselves. They termed this form of science 'ethology', as opposed to the 'pathology' which studied disease. It is important to emphasise here that Scott Williamson and Pearse did not regard their work as a form of preventive medicine. To think in such terms was, they believed, to prioritise the concept of disease over the concept of health. It is true that the regular physical overhauls required of the PHC's members revealed medical problems;

\footnotetext{
${ }^{5}$ Innes H. Pearse, 'The Peckham Experiment', Eugenics Review, 37, 2 (July 1945), 48.

${ }^{6}$ Pearse and Scott Williamson op. cit. (note 4), 7.

${ }^{7}$ Interview with Mrs Pam Elven, former Centre member, Cranleigh, 8 August 2013.
} 
but, as Alison Stallibrass has pointed out, the doctors were only enabling the members to alleviate or remove the pathological conditions preventing them 'from engaging in the process of health'. The Peckham doctors saw health as 'a process of realising one's potential for maturity [and] a mutual subjective synthesis of organism and environment and of person and group [which was] not something that members of the medical profession give us'. The word 'health' in common usage is intimately bound up with its opposite, being associated with remedial and therapeutic institutions and the care of sickness. The Peckham Experiment's primary aim was to foster an environment in which health (physical vitality, social confidence and development of skills and talents) could be cultivated: reduction of illness was a by-product of this. ${ }^{8}$

Although many assessments of the Pioneer Health Centre's work have been broadly, and at times strongly, sympathetic to its aims and achievements, it has not been without critics. David Armstrong goes so far as to describe its implications for observation of its members as 'terrifying', seeing it as part of a mid-twentieth-century extension of the 'medical gaze': something akin to Bentham's panopticon now widening its scope to include not merely the unwell but the behaviour of the community as a whole. ${ }^{9}$

Pyrs Gruffudd offers a more focused critique of the PHC by comparing it unfavourably with another modernist project of the 1930s, the Finsbury Health Centre in North London (1938). Gruffudd notes the PHC's political ambiguity as 'a retreat from State provision of health care', essentially a form of private medicine which regarded its members as 'distinctly gendered and autonomous individuals', in contrast with the self-consciously progressive message of Finsbury's Labour council, which saw the Centre's members as citizens 'for condensing through the social and ideological mechanisms of the Health Centre'. Whereas the Peckham doctors refused to compromise with the demands of Stateled medicine, the Finsbury Health Centre was 'an initiative by the local state of the type that formed the bedrock on which would be built the welfare state in the 1940s'. However, Gruffudd concludes by commenting that 'the Pioneer Health Centre Ltd charity has provided continued inspiration for practitioners of community-based medicine' and speculating that 'its ecological brand of conservative modernity [might] yet win out over the Welfare State that embraced Finsbury'. ${ }^{10}$

It must be emphasised here that the term 'health centre' as used by the Peckham doctors had a different meaning from the concept referred to in the 1946 National Health Service Act. As Michael Ryan points out, health centres were intended as a key feature of the NHS, since 'it was widely considered that bringing together curative and preventive work under one roof would do much to improve the quality of first-line medical care'. Under Section 21(1) of the Act, local authorities were required to provide, equip and maintain premises to be called health centres, where facilities would be available for general medical, dental and pharmaceutical services, any services local health authorities were required or empowered to provide, and facilities both for specialist and for outpatient treatment. ${ }^{11}$

\footnotetext{
${ }^{8}$ Stallibrass, op. cit. (note 3) 254, 255.

9 David Armstrong, 'The Peckham Key: Ideal Project and Terrifying Dream', Bulletin 33 of the Society for the Social History of Medicine (December 1983), 9-10. See also David Armstrong, Political Anatomy of the Body (Cambridge: Cambridge University Press, 1983), 36-38.

10 Gruffudd, op. cit. (note 1), 404, 410, 411, 412.

${ }^{11}$ Michael Ryan, 'Health Centre Policy in England and Wales', British Journal of Sociology, 19, 1 (1968), 34. The National Health Service Act, 1946 (London: Eyre and Spottiswoode, 1947), 21-22. Very few health centres were actually built in the years following the establishment of the NHS. See Charles Webster, The Health Services Since the War, 1: The Problems of Health Care; The National Health Service before 1957 (London: HMSO, 1988), 380-88.
} 
For Scott Williamson and Pearse, these proposed centres were merely a variety of services under one roof, dealing chiefly with sickness and remedial treatment. Only the PHC, they believed, seeking as it did to encourage health and to observe and understand its laws, could genuinely claim to be a health centre.

There has been a persistent sense that the Pioneer Health Centre offered an approach to health preferable to that which the NHS adopted, and that many of the problems with which the NHS has had to struggle - not least its cost - could have been avoided had the Peckham philosophy been put more widely into practice: a hope which seemed, in the mid-1940s, to have some justification. In The Nation's Health, published in 1944 in the series 'Target for Tomorrow' (whose editorial board included Sir William Beveridge, John Boyd Orr and Julian Huxley), the PHC was praised for its belief that a doctor's task should be 'to make people as healthy as possible, not simply to attend to them once they are ill', and for its 'recognition of the part played by social activities and relationships in total health'. The book ended with praise for the Centre, recommending that 'similar centres should in time be set up elsewhere, both for the collection of data about people in supposedly normal health, and for the re-creation of family and community life'. So why did this not happen, and why, when during the late 1940s the PHC had been receiving a constant stream of visitors, many of them highly distinguished, and was the subject of a film by the noted documentary-maker Paul Rotha, did it have to close early in $1950 ?^{12}$

The NHS has been a chief suspect or scapegoat for the death of the Pioneer Health Centre, apparently on the basis of the philosophical fallacy post hoc ergo propter hoc, since the Centre's demise occurred little more than eighteen months after the NHS was established. An editorial in The Medical Press and Circular saw the PHC as not fitting into the pattern of the new service, which it deemed 'too rigid and inflexible to contain it'. Mary Langman (1908-2004), who was secretary to Scott Williamson and later ran the Centre's farm at Bromley Common in Kent, believed that the Centre closed because of 'post-war inflation and lack of political will: it was an embarrassment to the architects of the National Health Service, which took ... no thought for the cultivation of health'. In 1974, the architect Peter Ray, who designed A Field Centre for the Practical Study of Human Ethology, wrote dramatically in the introduction to his project that the Peckham Experiment had been 'swept away on the high tide of Socialism which rose after the Second World War'. Former members of the Centre, interviewed by John Nye in 1984, said with some bitterness that 'The government wouldn't help' and that 'The National Health smashed it'. David Goodway, in a more recent assessment, quotes an article in the anarchist journal Freedom which blamed the post-war Labour government for rejecting the Peckham example in favour of a 'top-down, state-controlled bureaucratic national sickness system', and urged the transformation of the NHS into 'a decentralized, community-led organization' ${ }^{13}$

\footnotetext{
12 James Mackintosh, The Nation's Health (London: Pilot Press, 1944), 13, 24, 64. Paul Rotha's film The Centre was made for the Central Office of Information in 1947 http://blog.wellcomelibrary.org/2015/04/the-pioneer-he alth-centre-and-positive-health/.

${ }^{13}$ The Medical Press and Circular (12 September 1951), 245. Mary Langman, undated typescript of 'Approximate Dates and Places' for Scott Williamson and Pearse; copy in author's possession. Peter Ray, A Field Centre for the Practical Study of Human Ethology (Wellcome Library [hereafter WL] file SA/PHC/C.4/2), iv. John Nye, 'Reminiscences of St Mary's Road, Peckham' (WL/PHC/C.20, Appendix 6). David Goodway, 'Anarchism and the Welfare State: The Peckham Health Centre', History and Policy (May 2007).
} 
This article will argue that the reasons for the PHC's closure were more varied and complex than such comments imply, and that the NHS was by no means the chief villain of the piece. Drawing on hitherto unseen material from Mary Langman's papers, it will show that the personalities of Scott Williamson and Pearse contributed to the PHC's problems; it will consider the part played by the Medical Research Council; it will examine the nature of the debates which took place between the Centre and London County Council; and it will suggest some broader medical and cultural reasons why the Centre's approach came to be seen as marginal or irrelevant in the post-war period.

\section{Relations with the Medical Research Council}

The simplest possible answer to the question 'Why did the Pioneer Health Centre have to close?' is 'Lack of money'; but this merely raises the further question of why it could not find the necessary funds. The important fact to note is that the Centre had always struggled for funds; its history had been one of begging all the way, according to the first edition of its glossy journal Peckham. Certainly it had been struggling ten years before the NHS was established. The PHC's report for 1938/39 revealed that by August 1938 its position had been 'desperate', with its overdraft almost at the $£ 10,000$ limit. A $£ 2000$ loan kept things afloat until the situation was saved in July 1939 by a $£ 5000$ gift from Lord Nuffield, a gift of $£ 1000$ from an anonymous donor, and a further $£ 1000$ the following month from the Pilgrim Trust. The Centre then closed when war was declared. The Executive Committee had anticipated that the Centre could be run, within three years, at a cost coverable by subscriptions and members' expenditure, but this proved not to be so. Aiming to enrol 2000 families in order to achieve financial self-sufficiency, the Centre had by December 1938 attracted only 673, despite having that autumn extended its catchment area fivefold, thereby creating a potential membership of 25000 families. But there was a very disappointing response to this change: only $5 \%$ of those circulated went to visit the Centre, and only $2 \%$ actually joined. Reasons suggested in the 1938/39 Report included inconvenience (because of a greater distance to walk or push a pram); the cost of membership, and worry about unaccompanied children having to cross main roads. Nevertheless, the Report was optimistic that over a six- to ten-year period, the health service which the Centre provided could become self-financing. It was not just members that the Centre sought, however; it wanted to gain official recognition and public support for its work and so qualify for grants for various aspects of its research: medical, biological, social and educational. To this end it had been in touch with the Medical Research Council (MRC), 'who were considering the nature of [the Centre's] material with a view to grants in aid'. ${ }^{14}$

Before the war, the MRC appears to have been well-disposed, although not without some doubts. In a letter to the statistician Austin Bradford Hill, dated 4 May 1939, MRC Secretary Sir Edward Mellanby said that he wanted to help improve the PHC's status and find money for it. However, he added the caveat that 'the work may be of such a nature that it can lead nowhere from a scientific point of view'. Bradford Hill visited the Centre and, in a letter to Mellanby of 25 May 1939, said he thought that it was doing very useful work in preventive medicine but that the records were 'scribbled down' so that only the compilers could interpret the entries. He felt that Scott Williamson needed to develop a

14 Peckham: The Bulletin of the Pioneer Health Centre, 1, 1 (May 1949), 2. The 1938/39 Report is dated April 1940 (WL/SA/PHC/A.2/11); the quotations are from pages 15, 13-14, 15, 18. 
clearer research scheme and a well-defined form of record-keeping. On 30 May 1939, Lord De la Warr, at the Board of Education, wrote to Mellanby saying that Herbert Morrison of the London County Council (LCC) thought the LCC could make a grant to the PHC under Section 86 of the Education Act relating to Community Centres. ${ }^{15}$

At this point, there starts to emerge what would become a familiar pattern in the history of the Pioneer Health Centre, with one body expressing its willingness to help the PHC if another was also willing to do so. De la Warr said that the MRC would be willing to pay the PHC to undertake work on its behalf, but only if it could be assured that the Centre would continue to exist. A certain O'Brien at the Rockefeller Foundation would be willing to recommend help for the Centre, but Mellanby would need to show that he was officially interested. There were various people, 'all friendly', but all waiting for someone else to jump first. Mellanby wrote to Scott Williamson on the fourteenth of June saying that he would 'move' at the MRC to help as soon as possible, but that the Council 'could only take action on advice from people like Hill and others'. In a letter to Lord Nuffield of 8 June 1939, De la Warr identified another problem which would hamper the PHC's quest for funding: the Centre's work did not fall within the limits of any recognised public health or education service, and, although this was in itself a valuable feature of that work, it made it hard for the government to act under its statutory powers. It appears that it was largely thanks to De la Warr that Lord Nuffield made his substantial donation to the PHC, for in this same letter he described the Centre's work as 'of quite outstanding value and importance'. Eight days later, Scott Williamson was able to write to Mellanby to say that he had received Nuffield's $£ 5000$. $^{16}$

De la Warr also encouraged Thomas Jones of the Pilgrim Trust to put pressure on Mellanby, who, in a letter to Jones (4 July 1939) said that the MRC would be only too happy to promote scientific investigation at the PHC, but that 'the effort to get the place going has up to the present been incompatible with the close control necessary for scientific observation'. If the Pilgrim Trust put some money up for 'this interesting social experiment, the Medical Research Council would probably interest themselves in it and endeavour to make it a more effective place'. The Pilgrim Trust did so, but the outbreak of war intervened and the Centre had to close. In any case, the word 'probably' has all the appearance of a let-out. ${ }^{17}$

The war over, Scott Williamson was rapidly back in contact with Mellanby, who remained cagey, saying in a typed note dated 7 September 1945 that the MRC would be glad to use for investigation the facilities offered by the Centre 'if a suitable scheme were put forward'. Presumably none was, for two years later - the Centre having re-opened in the spring of 1946 - the situation was still at stalemate. By this time, J. A. Charles of the Ministry of Health was involved. In reply to a communication from Charles, Mellanby wrote on 13 August 1947 as follows: 'We were anxious to help them just before the war but found that all their records were untidy, and we were unable to make use of them for statistical analysis. We then had the idea of asking Bradford Hill to look into their methods of recording, in order to see whether we could improve them, and this was all agreed upon when war broke out ...' Charles thought that the Ministry of Health might be able to

\footnotetext{
15 Correspondence in National Archives [hereafter NA] file FD1/299.

${ }^{16} \mathrm{Ibid}$. The O'Brien in question was probably Dr Daniel P. O'Brien, an assistant director at the Rockefeller Foundation. I am grateful to an anonymous referee for pointing this out.

${ }^{17}$ Ibid.
} 
help under the wide powers of Section 16 of the National Health Service Act, but first he wanted to know if the MRC was still interested. ${ }^{18}$

From this point on, the MRC's tone grew increasingly unfavourable. Mellanby's MRC colleague Arthur Landsborough Thomson was downright dismissive in an undated memorandum referring to a memorandum about the PHC which had been forwarded to him with a letter from J. A. Charles dated 15 September 1948. He quoted from the memorandum and underlined passages which he said 'illustrate what the writers mean by "research" - apparently investigation of cases with a view to their treatment'. Among the material underlined is 'with the purpose of cultivating health', and 'To provide for efficient medical attention for these cases what is needed is a small research team to deal with the $80 \%$ ' ${ }^{19}$ Here indeed is some evidence for the view of the epidemiologist Archibald Cochrane that the MRC had a 'well known bias towards pure research' and 'a limited record of initiating research into "problems of immediate importance" '; also for Lord Moynihan's view that the MRC was more concerned with mice than with humans and was aloof from day-to-day medical practice. ${ }^{20}$

The MRC thereafter played an important part in stifling the hopes of the Pioneer Health Centre. A confidential document of April 1950 [no day specified] about the Centre which by then had closed - was sent to the Lord President of the Council by the Labour MPs Freda Corbet (Peckham), John Cooper (Deptford) and Wilfred Vernon (Dulwich). They argued that the Centre's work fell naturally within the MRC's province, quoting, from its 1945-48 Report, its stated aim of promoting 'scientific investigation for the acquisition of knowledge likely to be of value for the prevention, diagnosis and treatment of disease, and for the maintenance of normal health and FULL HUMAN EFFICIENCY'. The MRC, they believed, concentrated too much on disease. 'We believe that the present Governors would agree to transfer the whole enterprise to the Nation if the Medical Research Council would assume responsibility for its future, and continue the work on the lines already laid down.' Major Vernon invited Harold Himsworth of the MRC to lunch at the House of Commons (13 May 1950), and Scott Williamson wrote to Himsworth ten days later enclosing the PHC's research programme. However, this included statements unlikely to have strengthened the Centre's case. He wrote, for instance, that the experiment had 'no relation to laboratory experiments in the exact sciences'; that it could not use exact control as in physiology, and that it was not a medical experiment in the sense of studying specific diseases. On the day that Scott Williamson sent this letter, Vernon

\footnotetext{
18 NA/FD1/299. Section 16 (1) of the National Health Service Act, 1946, states that 'the Minister may conduct, or assist by grants or otherwise any person to conduct research into any matters relating to the causation, prevention, diagnosis or treatment of illness or mental defectiveness'.

19 NA/FD1/299.

${ }^{20}$ Archibald L. Cochrane, One Man's Medicine (London: British Medical Journal, 1989), 244, 245. Jane Austoker and Linda Bryder (eds), Historical Perspectives on the Role of the MRC (Oxford: Oxford University Press, 1989), 214. The MRC did in fact attempt to come to grips with practical problems, establishing its Social Medicine Research Unit (SMRU) in 1948. But as Shaun Murphy has shown, there was considerable tension between Harold Himsworth, who became MRC Secretary the following year, and Jerry Morris of the SMRU, with Himsworth sceptical about the value of the Unit's work. In any case, the work carried out by Cochrane in South Wales, for instance, was very different from the work being attempted in Peckham. Cochrane was focused on disease, not health; and - crucially important as a matter of scientific methodology - the data his team gathered were not the result of self-selection, unlike the population being observed at the Pioneer Health Centre. Shaun Murphy, 'The Early Days of the MRC Social Medicine Research Unit', Social History of Medicine, 12, 3 (1999), 389-406.
} 
wrote to Lord Addison, saying that the MRC was the only body competent to direct the PHC's researches. ${ }^{21}$

There followed a rapid exchange of letters between Himsworth, on the one hand, and Scott Williamson and Vernon on the other. Himsworth proved a master of delaying tactics, writing to Scott Williamson on 30 May 1950: 'I think it would be wiser to postpone any discussion as to the possible role of the Medical Research Council in the future scheme, until an approach has been made through the official channels'. Scott Williamson replied the next day that as both the Ministry of Health and the London County Council had found it impossible to use the PHC for research into health, the Centre would either go up for sale or be given to anyone willing to carry on the work. 'I would prefer to give the assets of the Centre for Research purposes - into Health - not for Medical Research. [. . . ] I conclude the M.R.C. does not want to consider it - even as a gift. Sorry to have troubled you.' Scott Williamson seems to have been offering the Centre to the Medical Research Council in the hope that it would not be used for purposes of medical research. ${ }^{22}$

Himsworth and Addison collaborated on a response to Vernon. An undated draft by Himsworth of a suggested letter that Addison might write contained the following comments on the PHC's apparently dilatory approach: 'No precise proposals for research have yet been submitted to the Council', which had been unable to discover 'that investigations which they could justifiably support were in progress'. On 15 June 1950 he wrote to Addison about the draft and admitted to having made a 'non-committal' reply to Scott Williamson's letter. Addison's reply to Vernon was dated the same day. It used Himsworth's draft, but, where Himsworth had suggested saying that any proposals from the PHC would be considered 'sympathetically', Addison struck out that adverb. ${ }^{23}$ According to Scott Williamson, writing to J.G.S. ('Jack') Donaldson on the seventh of June, the '“administrators" (not the government)' - by which, given the context, he appears to have meant the MRC - found the PHC 'a thorn in their flesh; privately they have told us so. [... ] I am angry that they would not even risk making the P.H.C. a Government Research Station ...' In a letter to 'Olive' of 6 February 1952, though, Scott Williamson laid the blame elsewhere. 'We could have got all the support we needed and more from all the Research Foundations if we had had the goodwill of the L.C.C. and the M.O.H. [Ministry of Health]' ${ }^{24}$ We shall look later at the role of these other bodies.

On the face of it, the point made by the three local MPs, quoted above, that the Pioneer Health Centre's work fell within the remit of the MRC, was quite valid. Why, then, might the MRC have found the Centre a thorn its flesh? We have seen that the Council concentrated its efforts on investigating disease rather than looking at how health might be encouraged and maintained. According to Mary Langman, everything at the Centre that could be measured, was; but, she asked: '[H]ow do you measure serenity? [... ] [T]his was the sort of problem in which the Medical Research Council showed no interest at all.' It was in fact one aspect of a broader problem: quantity could be measured, but how was quality

\footnotetext{
${ }^{21}$ NA/FD1/299. Christopher Addison (1869-1951), physician, agriculturalist and politician, had been Chairman of the MRC in 1948.

22 NA/FD1/299.

23 Ibid.

${ }^{24}$ J.G.S. Donaldson (1907-98) was a wealthy socialist who, as a young man, gave half his fortune to the Pioneer Health Centre. He served as Minister for the Arts in the Labour government of the late 1970s, later joining the Social Democratic Party. His support for the Pioneer Health Centre was lifelong. WL/SA/PHC/B.6/10. WL/SA/PHC/B.6/1.
} 
to be scientifically assessed? For we should be clear that Scott Williamson insisted that he was only interested in 'pure Science', but believed that science in Britain was affected by 'the fell disease "Orthodoxy"'. The MRC would have been, to Scott Williamson's eyes, a prime exemplar of this tendency. ${ }^{25}$

\section{Relations with London County Council}

We saw above that Scott Williamson held the London County Council and the Ministry of Health accountable for the Pioneer Health Centre's inability to attract funding from research establishments, and material in the London Metropolitan Archives illustrates how these two bodies responded when the Centre approached them for support. The Centre did not help its cause by stating explicitly that it was not a medical organisation, but cultural and educative, and that its breadth meant that it was no-one's specific responsibility. This was a point with which Sir Allen Daley, Medical Officer of Health for the LCC, and Sir Graham Savage, the LCC's Education Officer, wrestled as they tried to solve the problem of the PHC's future. Writing to A. Reginald Stamp, Chairman of the LCC's Health Committee (10 May 1949), Daley said truistically that the PHC was 'doing pioneer work', but was outside the provisions of the 1946 National Health Service Act. Perhaps, he suggested, it could be given a grant under Section 28, relating to care and after-care; or perhaps it could get one under Section 53 of the 1944 Education Act, relating to voluntary organisations maintaining community centres. Daley had discussed the matter with Savage, who agreed that the PHC was doing very good work, but thought it 'difficult to bring [the Centre] under any new scheme which the local authority could subsidise'. Two days later, Stamp told J.W. Bowen, Chairman of the LCC, that the PHC insisted on family membership, including payment, and that this was not permissible under the 1946 Act. Bowen had been approached by Lord Lindsay, a long-term supporter of the PHC, and now responded (24 May 1949) by saying that the Centre was a praiseworthy 'many-sided social experiment', but that 'many difficulties [stood] in the way of granting assistance to the Centre' and were likely to prove 'insuperable'. ${ }^{26}$

The following month, Stamp and Daley held an informal conference with C. D. Wilson and Major Short of the PHC, at which Short said that his chief interest was in the PHC's health work. Stamp emphasised that voluntary organisations had to conform to the Education and National Health Service Acts; if the Centre did not, it was practically impossible for local authorities to make contributions to its work. Under the National Health Service Act it would be impossible to provide help if non-members could not be admitted. He suggested that the Centre might alter its constitution in the light of the Acts, but Wilson rejected this option. By February 1950 the Centre was again in the position where no-one would jump unless someone else did. In a letter to Daley (23 February), Wilson said that no Trusts would make a grant unless the LCC and the government would officially guarantee the Centre's continuation and development. ${ }^{27}$

\footnotetext{
${ }^{25}$ Mary Langman, unpublished typescript of a talk entitled 'Management', with 'May 1987' pencilled in at the top, 6-7; in author's possession. Undated draft letter from Scott Williamson to Gregg of the Rockefeller Foundation (WL/SA/PHC/B.3/13/2).

${ }^{26}$ Peckham: The Bulletin of the Pioneer Health Centre (May 1949), 4. London Metropolitan Archives [hereafter LMA] file CL/PH/1/131. A.D. Lindsay (1879-1952), Master of Balliol (1924-49) and founder of Keele University, had provided a Preface for Pearse and Scott Williamson's The Case for Action in 1931.

${ }^{27}$ LMA/CL/PH/1/131.
} 
The Centre closed at the beginning of March. The LCC claimed that it had made an offer of help to the Centre, but Scott Williamson disputed this in a letter of 7 March. All he had received, he said, was a verbal assurance that the Council would help if the PHC were prepared to abandon the policies of family membership, a defined locality for the member families and a periodic health overhaul. To have done so would have changed the whole purpose of the Centre. On 16 March, the LCC's Clerk wrote to Scott Williamson, emphasising that any financial assistance it might provide would be dependent on the PHC's facilities being 'generally available to the public'. Scott Williamson was adamant that the Centre would not alter its constitution, and his reply (21 March) read, in toto: 'Thank you for your letter of 16th March, which clarifies the situation in a most valuable way'. 28

It is evident that by then the LCC had its own purposes in mind. Reginald Stamp (9 March 1950) sent a memo to the leader of the Council expressing impatience with the whole situation and suggesting that 'the only way to deal with this Centre is for us to get into a position to purchase the whole premises for educational and health purposes'. However, it looked for a while as though the Halley Stewart Trust might find a continuing scientific purpose for the PHC. This charitable body had helped fund the Centre from its re-opening in 1946, and its withdrawal of funding - it undertook only limited periods of support - had helped precipitate the Centre's terminal crisis. In the spring of 1950 it was looking at ways in which the PHC might undertake more effective scientific work on a different basis, and it commissioned an Interim Report by a Scientific Advisory Committee whose members included Professor D.V. Glass of the London School of Economics, Dr J.N. Morris of the MRC's Social Medicine Research Unit and Dr Max Rosenheim of University College Hospital. The Trust wanted to know the Centre's scientific value, and the Committee's report formed the Appendix to a joint report, dated 9 March 1950, by the LCC's Medical Officer of Health and Education Officer. ${ }^{29}$

The Committee felt that the PHC did not provide proper facilities for scientific research, on account of its inadequate research staff and its community being probably highly selected'. The best plan of development would be to turn the Centre into a Health Centre in terms of the 1946 Act, with a Research Institute of Human Biology attached and a family club continuing. The Research Institute would qualify for a grant under Section 16 of the Act, with research carried out in, and from, the Centre, by medical practitioners providing general services, others engaged in those services and 'others specially appointed' ${ }^{30}$

Nothing came of this proposal, and the LCC benefited from the PHC's governors' abandonment of any hope that the Centre could continue on its original lines. A Public Health Department memo of 27 April 1950 discussed possible uses of the Pioneer Health Centre building for health services; it said that the LCC could not give support by subsidising present activities for 600-800 families, and it demonstrated a lack of understanding of the Centre's purpose by suggesting that "If the "family club" idea is essential, it could be achieved by hiring accommodation for evenings to a voluntary body'.

\footnotetext{
${ }^{28}$ LMA/CL/PH/1/131. Section 21 (1) of the National Health Service Act, 1946, laid on every local health authority the duty to establish health centres providing facilities for general medical, dental and pharmaceutical services; any services local health authorities were required or empowered to provide, and facilities for outpatient and specialist treatment. The Pioneer Health Centre's aims were quite distinct from these proposed concerns, only a handful of which ever materialised. See Webster, op. cit. (note 11), 380-88.

${ }^{29}$ LMA/CL/PH/1/131.

${ }^{30}$ Ibid.
} 
This lack of understanding was further demonstrated at a conference at London's County Hall on 1 May. Major Short, Mrs Iris Montagu and Jack Donaldson represented the PHC; others present included the MP Freda Corbet, Drs Godber and Fenton from the Ministry of Health, Allen Daley, Sir Graham Savage and Reginald Stamp, who chaired the meeting. Stamp felt that the conception of health centres under the 1946 Act went a long way to meeting the existing aims of the PHC. Dr Godber said that he could not commit the Ministry of Health to any decision, but he had no doubt that a good case could be made for 'some form of medico-social research'. Allen Daley wanted to set up health and community services first, then local GP and dental group practices; only when these were established could a research institute be considered, but this was unlikely to happen for some time. On 26 May 1950, C.D. Wilson wrote to Sir Howard Roberts, Clerk of the Council at the LCC, to emphasise that the PHC's primary objects included positive health, regular health overhauls, family membership and a social field for family use. The institution which the LCC envisaged would not be a continuation of the original experiment and should bear some other name. A letter (28 July 1950) from Herbert Morrison to Reginald Stamp advised him on how to make the PHC's representatives bear responsibility for any breaking off of negotiations: they had the choice of either accepting the LCC's offer or of selling off the Centre and losing everything that had already been done. The Centre's representatives opted for the latter course, and from then on a major concern was the haggling over the price at which the LCC would buy the Centre and its assets. $^{31}$

One final point worth making concerns the noted health centre on the Woodberry Down estate in Green Lanes, North London. In a Ministry of Health Circular (3/48), issued on 14 January 1948, Aneurin Bevan wrote that he wanted 'intense expert scrutiny by a special committee or working party to be set up of the likely lines of first experiments' in the building and establishment of health centres. At a meeting of the LCC's Health Committee on 2 March 1948, it was agreed that the LCC should 'get an experimental health centre started [at Woodberry Down] as soon as possible'. This centre's opening in 1952 provides a somewhat symbolic contrast with the recent closure of the Pioneer Health Centre, demonstrating the LCC's firm sense of obligation to the provisions of the 1946 National Health Service Act. A memorandum from Sir Allen Daley makes it clear that the proposal for a health centre at Woodberry Down was for GPs and public health staff - the 'curative' and 'preventive' sides of the project - to work together. As we have seen, such an institution was not a 'health centre' in the Peckham sense of the term. ${ }^{32}$

\section{Tensions within the Pioneer Health Centre}

In their booklet The Passing of Peckham, published in the summer of 1951, Scott Williamson and Pearse gave an account of the Pioneer Health Centre's history, purpose and re-opening, and offered various reasons for the problems it faced. The doctors' hostility to the direction of post-war politics emerged at the point where they quoted an unnamed Director of a Foundation as saying that it could not support the PHC since to do so " "might be contrary to the undefined policy of the government". This appears to be the general attitude adopted by all foundations at the present time'. One would want to know, though,

31 Ibid.

32 LMA/PH/PHS/1/6. 
which foundation was being referred to, and whether this was what it really thought or whether it was making excuses. ${ }^{33}$

The doctors attributed the Centre's passing to its administrative irregularities: it was concerned with studying and cultivating health, not treating disease; it was based on the family, not the individual; it was based on a locality, having no 'open door' policy; it was not free, and it was based on autonomous administration, not conforming to the lines laid down by the Ministry. Above all, it 'arose out of an original conception which extends into a region beyond the ambit of present day Medicine and Hygiene [italics in original], and therefore is not eligible to receive the enabling stamp of Authority'. They concluded that:

‘. . a "Welfare State" must be the sole arbiter of its Nation's destiny. To maintain its integrity it can brook no influence that comes from outside its own programme of compelling "care". It is not yet ready to consider the possibility that the cultivation of order, ease and virtue in Society, might prove an even greater power for the welfare of the people than the abiding "care" of the administrator'. ${ }^{34}$

Scott Williamson was prepared to accept that the Centre had re-opened too soon after the war; it was dilapidated and lacked adequate research equipment. But there had been strong pressure to do so, not just from former members, but from influential supporters such as Lord Horder, Sir Malcolm Stewart and the publisher Stanley Unwin. With poignantly ironic optimism, Unwin opined that when the Centre re-opened 'the Universities will fall over themselves. [... ] We know that it will grow and that nothing can stop it'. ${ }^{35}$ There is evidence, though, that Scott Williamson did not help his own cause, and that he and Innes Pearse antagonised other senior figures at the Centre by the way they reacted to its problems.

In January 1984, Mary Langman wrote a long letter to Douglas Trotter about the PHC's history and its demise. As a young man training for ordination Trotter had been sent by George Macleod, founder of the Iona Community, to see what was happening at Peckham; Macleod was particularly interested in other experiments in community. Trotter, who later became an academic theologian at St Andrews University, met his future wife at the PHC (they married in 1949) and remained committed to the Centre for the rest of his life. Langman's letter is very frank about the inadequacies of Scott Williamson and Pearse (whom she nevertheless much admired), implying that not all the blame for the PHC's

33 G. Scott Williamson and Innes H. Pearse, The Passing of Peckham (London: Pioneer Health Centre, 1951 ), 7. The body in question may have been the Rockefeller Foundation, since the South London Observer of 17 August 1950 quoted Mrs Purser as saying that the Rockefeller Foundation would help the PHC if the government was prepared to recognise it officially. (The relevant cutting can be found in LMA/PH/PHS/1/7.) Whatever the truth of this, gaining funds from that body was always going to be difficult for the PHC. For a quarter of a century the Foundation awarded grants to the MRC, enabling it to send abroad British students for advanced training in medical science: appointees had included Sir Howard Florey and the animal geneticist Dr C.H. Waddington. The PHC's status would have struck the Rockefeller Foundation as very marginal in comparison with that of the MRC. Also, as Robert Kohler's study of the relationship between charitable foundations and the natural sciences during the first half of the twentieth century demonstrates, towards the middle of the century grants became increasingly hard to obtain as scientific methods grew more complex. The large foundations were 'cultural transmission belts, carrying business methods and managerial values from the world of the large corporations into academic science'. Kohler concludes that by 1945, 'The age of "big science" had begun'. Medical science would be dealing with the daunting problems of the post-war world. One can see that the PHC, dealing with a small, self-selected population of reasonably comfortable citizens, might not have struck the charitable foundations as a priority. Raymond B. Fosdick, The Story of the Rockefeller Foundation (London: Odhams Press, 1952), 293. Robert E. Kohler, Partners in Science: Foundations and Natural Scientists, 1900-45 (London: University of Chicago Press, 1991), 395, 396, 406.

${ }^{34}$ Scott Williamson and Pearse, op. cit. (note 33), 8, 10.

${ }^{35} \mathrm{WL} / \mathrm{SA} / \mathrm{PHC} / \mathrm{B} .4 / 4$. 
problems could be projected on to the Welfare State. Langman expressed doubts about Scott Williamson's capacity as a communicator of ideas. He was, she said, unable 'to convince anyone (? also himself) that he was able to cope with the research problem he had opened up - even where, which was not often, he was able to make them see what it was. That was, to devise means of assessment and "measurement" for quality'. ${ }^{36}$

Langman's letter confirms that Harold Himsworth's suspicion of a split within the Pioneer Health Centre was correct. She writes of the doctors' 'tactical unwisdom' and of the 'dialogue of the deaf' that they conducted with those who tried to help them. 'The tag that went through my mind was "those whom the gods wish to destroy they first make mad"'. They suffered, in Langman's view, from the character flaw of an 'inability to recognise that any of their colleagues ... had any essential contribution to make to the experiment'. Major Short, who, as we have noted, at times negotiated on their behalf, considered them 'megalomaniacs', and R. P. Winfrey, who had through the Halley Stewart Trust given the doctors much support over many years, found that at the end he "could not talk to them, nor they to him'. C.D. Wilson found himself in the position of 'trying to "save the Centre in spite of the Doctors", Minutes of a meeting held on 23 March 1950 provide refer to 'internal dissensions and misunderstandings' which could not be tolerated any longer. Langman was open in her private letter to Douglas Trotter, but prepared to be 'economical with the truth', as we would now say, where the outside world was concerned. She expressed her relief that Jane Lewis, who with Barbara Brookes had published two major articles on the Centre in 1983, 'got no wind of all this'. We should note, though, that Lewis and Brookes do attribute Scott Williamson's problems in part to his personality. ${ }^{37}$

Scott Williamson does seem to have lacked diplomatic skills. A letter from him to Aneurin Bevan (undated, but perhaps from 1946, as it refers to Bevan's 'Bill') exhibits a distinctly abrasive and impatient tone. 'It now appears,' he wrote, 'that my Research work which created Peckham as a Unique and Original approach to the Social Problems of Health is not likely to get Funds under your Bill - because it does not fit into Orthodox Medical Research ...' The PHC was a research proposition having nothing to do with medicine or the care of the sick, he emphasised; but how would that have helped persuade Bevan that the Centre deserved assistance? Scott Williamson asked forgiveness for his 'indignation - but we are wasting precious time begging for money to keep the door open in Peckham - and I would prefer to give time to Research - Original not orthodox; for we do NOT fit into any existing line of research'. ${ }^{38}$

Scott Williamson particularly resented the criticism that the Pioneer Health Centre was not self-supporting. Had it achieved this aim, its independence would have been guaranteed; but it did not do so, either before or after the war. For Scott Williamson, this was not a reason to condemn the Centre, which was a 'Living Sociological Entity' with its own inherent rate of growth, that could not be forced. The Centre's post-war social environment, though, meant that the rate of growth was likely to be slow. Not only was the Centre itself in poor repair, but 'War had dislocated the life of the district and

\footnotetext{
${ }^{36}$ Mary Langman to Douglas Trotter, 2 January 1984; letter in author's possession. Interview with Henrietta Trotter, 27 June 2006.

${ }^{37}$ Mary Langman to Douglas Trotter, 2 January 1984; letter in author's possession. WL/SA/PHC/B.6/1. Jane Lewis and Barbara Brookes, 'A Reassessment of the Work of the Peckham Health Centre, 1926-51', Health and Society, 61, 2 (1983), 341.

38 WL/SA/PHC/B.5/16/1.
} 
dissipated many of the family-members of the Centre' ${ }^{39}$ This in itself, though, does not explain why the Centre, which was internationally renowned, could not attract sufficient member families to enable it to break even. It may be that the introduction of the NHS, ironically, encouraged people to be less concerned about health because they could now have free treatment for illness; but that theory would apply only from the summer of 1948, about eighteen months before the PHC closed, by which time it had been open again for more than two years. It may be that adolescents were reluctant to spend their leisure time with their families, and that there was a desire to enjoy the privacy of domestic life after the upheavals of war-time and the collectivism which they necessitated. No definitive explanation, however, can be arrived at. Only those Peckham families - the overwhelming majority - who did not join the Centre could have provided the answer.

It should be clear by now that the NHS can hardly be regarded as the chief cause of the Pioneer Health Centre's demise. We can therefore widen the focus and mention some of the more general features of medicine and science which provided an unsympathetic context for the Centre's struggles.

\section{The Wider Context: Developments in Medical Science}

In 1935, the year that the Pioneer Health Centre's modernist building opened, the British Postgraduate Medical School was established at Hammersmith Hospital, committed to promoting specialist research in order to advance medical knowledge. Its work, according to James Le Fanu, 'ensured the style of medicine epitomised by the School - "clinical science" - would ... revolutionise the practice and philosophy of medicine'. Le Fanu contrasts the attitudes of two prominent clinicians, Lord Horder and Sir Thomas Lewis: a particularly interesting choice for our purposes here, since Horder was closely involved with the work of the PHC. Horder was a traditional doctor in the Osler mode, excellent at providing a diagnosis based on a patient's history and physical symptoms. The essence of his approach was a personal relationship between doctor and patient, with little or no use of technology. Lewis, on the other hand, used electrocardiogram technology to produce a magisterial study of the heartbeat, and paved the way for applying the methods of physiological investigation to human patients. One of his most important followers, John McMichael, experimented with inserting catheters into the heart to measure the fall in pressure following blood loss. Le Fanu describes the significance of this as follows: 'Here, then, is the decisive moment when the focus of medicine shifts from the Horder view of a professional contract ... to one where the welfare of the patient is subordinated to the progress of science.' In this new world, patients became “ "interesting clinical material" on whom the ambitious young doctor performs his experiments with a view to publication in a prestigious medical journal.' One consequence of this approach was that specialist research gained enormously in status. ${ }^{40}$

\footnotetext{
${ }^{39}$ Scott Williamson to R.P. Winfrey, 2 January 1951 (WL/SA/PHC/B.15/5). Scott Williamson and Pearse, op. cit. (note 33), 3 .

40 James Le Fanu, The Rise and Fall of Modern Medicine (London: Abacus, 2012), 224, 230. It may be that Le Fanu has over-simplified for dramatic effect. Rosemary Wall has argued that 'from the 1920s to the 1940s, Horder publicly supported specialisation in general in medicine, not just within the laboratory' and 'was happy to use specialists, diagnosing patients away from the bedside'. Nevertheless, she records that he became worried about his patients' increasing faith in technology and in experts, and their concomitant scepticism about their clinician's depth of knowledge. Le Fanu's identification of the trend towards a more specialised, technologically based medicine remains valid. Rosemary Wall, Bacteria in Britain, 1880-1939 (London: Pickering and Chatto, 2013), 58, 62.
} 
Another factor posing problems for the PHC's work was the growing influence of statistical analysis in medical science. As we saw earlier, interpretation of the Centre's records had been a matter for discussion before the Second World War, with the Medical Research Council involving Austin Bradford Hill in examining the data. In 1945, Bradford Hill became Professor of Medical Statistics at the London School of Hygiene and Tropical Medicine, and Honorary Director of the MRC's Statistical Research Unit, at a time when the importance of statistics was growing rapidly. His classic textbook quotes Helmholtz: 'All science is measurement'. Hill believed that records were without value unless kept as part of a planned experiment, and that random sampling was essential. ${ }^{41}$

H.I. Winner had made a similar point in the journal Scientific Worker at the time of the Centre's closure. Winner argued that The Peckham Experiment (1943) by Innes Pearse and Lucy Crocker, was full of 'woolly statements about a variety of sociological topics which would not stand scientific examination'. There had been no statistical sampling, whereas nearly all academic centres of social medicine were chiefly concerned with statistical studies. Much more was needed than a small sample of the population. (One might suggest that this 'more' was exactly what Scott Williamson was hoping could be achieved, when he approached the Medical Research Council.) Sir Henry Dale praised the 'calm and ruthless logic of the statistical method' for giving 'a higher level of scientific authority to the planning of investigations and the appraisement of their results'; this branch of science had 'quietly but irresistibly' come to exercise a corrective influence, substituting a numerical measure 'for the vague and speculative methods of appraisement which formerly prevailed' ${ }^{42}$ The PHC's work was inadequate according to these criteria, as a particular definition and understanding of science began to overshadow alternatives.

The MRC's ethos had been shaped by the dominant influence of Walter Morley Fletcher, who believed that research work required concentration on some particular disease or some special aspect of disease. His approach fostered small specialised committees of a scientific elite 'able to exert control through the selective support of certain individuals and areas of research at the expense of others', believing that medical practitioners were incapable of co-ordinating scientific activities. Landsborough Thomson, at the beginning of his two-volume history of the MRC, quotes approvingly what Rockefeller's adviser F.T. Gates wrote in 1897: 'Medicine can hardly hope to become a science until it can be endowed, and qualified men enabled to give themselves to uninterrupted study and investigation, on ample salary [my italics], entirely independent of practice'. Early in the second volume, Landsborough Thomson is scathing about certain proposals for treatment of TB, but his comments might equally apply to a project such as the Pioneer Health Centre: 'The promoters tended to stimulate pressure groups of patients and busybodies, anxious to champion the supposed pioneer against the alleged tyranny of the professional "closed shop", The disdain is palpable. ${ }^{43}$

It is interesting to discover in Appendix C of Thomson's history, which lists the MRC's research establishments, that more than 30 of these establishments were disbanded when

\footnotetext{
41 Austin Bradford Hill and I.D. Hill, Bradford Hill's Principles of Medical Statistics, 12th edn (London: Edward Arnold, 1991), 5.

42 H.I. Winner, 'The End of the Peckham Experiment?', Scientific Worker V, iv (July 1950), 19. Sir Henry Dale, 'Scientific Method in Medical Research' British Medical Journal, 2 (1950), 1189.

${ }^{43}$ Austoker and Bryder, op. cit. (note 20), 212, 27, 29. A. Landsborough Thomson, Half a Century of Medical Research, 1: Origins and Policy of the Medical Research Council (UK) (London: Medical Research Council, 1987), 2; Half a Century of Medical Research, 2: The Programme of the Medical Research Council (UK) (London: Medical Research Council, 1987), 9-10.
} 
their Directors either retired or died. To approach the same issue from a more personal angle, Sir Peter Medawar's memoirs offer an insight into how things worked in the world of the MRC. 'Some time in the summer of 1960 the then administrative head of the Medical Research Council, Sir Harold Himsworth, invited me to lunch at his club, abetting his advocacy by that well known to be exercised by Chateau Cheval Blanc. He put it to me that when the then incumbent Sir Charles Harington retired in 1962, I should take over the Directorship of the National Institute for Medical Research at Mill Hill.' Despite Landsborough Thomson's lofty pretensions to purity of research and 'the advancement of natural knowledge that might, eventually, and perhaps only indirectly, help towards the solution of practical problems of medicine', it is hard to avoid the suspicion that this was a world of 'jobs for the boys'. ${ }^{4}$

\section{The Wider Context: Chemical Triumphalism}

One notable feature of the cultural context in the post-war period was what might be termed a 'chemical triumphalism' which swept through both medicine and agriculture. The achievements of science and technology during the first half of the twentieth century created - at least among scientists and industrialists - a sense that humanity's problems could be solved by the application of ever more exciting and effective discoveries. Dr Willard Dow of Dow Chemicals provided an example of such optimism on the occasion of his receipt of the Chemical Industry Medal in November 1946, referring to Science's successful interpretation of Nature's laws and to industry's successful employment of scientific discoveries for 'the useful purposes of mankind', which led in turn to the progress of civilisation. Nature's immense riches were ready to be tapped by industry, or, as Dow expressed it: 'The industries of the world are standing ready to offer their every assistance'. The people who maligned these efforts were, said Dow, 'traitors to civilization' and 'economic parasites' who were 'destined to destroy themselves; for in an advancing civilization there is less and less room for recalcitrants'. A similar mind-set could be found in Britain. Professor C. N. Hinshelwood, President of the Chemical Society, spoke at the Society's centenary dinner in 1947 on how chemistry offered rich gifts for 'conquering disease, providing food and enabling us to obtain all [sic] that made life worth living'. The agricultural scientist Sir John Russell was similarly optimistic. From 1912 until 1943 Russell had been the Director of Rothamsted Experimental Station in Hertfordshire, the chief centre in Britain for research into chemical fertilisers. As President of the British Association for 1949, he waxed lyrical about the limitless possibilities of science and how the efforts of chemists 'could not fail to bear fruit' so long as scientists 'had a sustaining faith, a high purpose in life and unflinching courage to pursue it'. ${ }^{45}$

Russell's views are directly relevant to the history of the Pioneer Health Centre, as he was a leading opponent of the organic school of farming, which during the Second World War had started to organise its opposition to industrial-chemical agriculture. Jane Lewis and Barbara Brookes refer disparagingly to the fact that 'some Peckham staff members were known to be involved in a related, dubiously scientific venture, called the Living Soil Society, which was founded by Lady Evelyn Balfour'. This was in fact the Soil

\footnotetext{
${ }^{44}$ Landsborough Thomson, op. cit. (note 43), Vol. 2: 352-70. Peter Medawar, Memoir of a Thinking Radish (Oxford: Oxford University Press, 1991), 136. Landsborough Thomson, op. cit. (note 43), Vol. 2: 3.

45 Chemistry and Industry, 11 January 1947, 21, 20; 26 July 1947, 457; 10 September 1949, 637-8. The statistician and eugenicist R.A. Fisher worked at Rothamsted from 1919 to 1933, Russell being instrumental in employing him there. Sir E. John Russell, The Land Called Me (London: Allen and Unwin, 1956), 131-2.
} 
Association, founded in 1946, which for seventy years has been the leading body in the promotion of organic food and farming. Scott Williamson, along with Eve Balfour (18981990) and the farmer and racehorse breeder Friend Sykes (1888-1965) of Chute, near Andover, was one of its three begetters. Innes Pearse, Mary Langman and Dr Kenneth Barlow (1906-2000), a Coventry GP who worked at Peckham for a time in the late 1940s, were founder members of the Association; Langman, the daughter of a Somerset dairy farmer, ran the farm at Bromley Common in Kent which supplied the PHC with fresh humus-grown foodstuffs. In 1943 Balfour's book The Living Soil had appeared, subtitled 'Evidence of the importance to human health of soil vitality, with special reference to post-war planning'. The Soil Association had as its first aim 'to bring together all those working for a fuller understanding of the vital relationships between soil, plant, animal and man'; in other words, its prime concern was with health, and it believed that it was crucial to investigate whether agricultural methods affected the health of plants, animals and humans. There was some evidence to suggest that the enrichment of soil through the creation of humus did indeed have beneficial effects, and Balfour and her colleagues argued that if this were so (further experimentation being essential), then organic farming and the production of humus-grown crops would become a form of health service. ${ }^{46}$

The parallels with the ideas of the Pioneer Health Centre should be clear. A humusrich soil would produce healthy plants and animals, which would feed an increasingly healthy population. Any need for the paraphernalia of sprays, weed-killers and other features of the chemical weaponry would similarly be reduced. Chemical fertilisers, with their potential danger to soil bacteria, earthworms, and human health, would become increasingly unnecessary. The Centre provided a social 'soil' in which healthy human plants could develop; the reparative work and expense of treating disease would be reduced. The philosophy of both the PHC and the Soil Association was biological and ecological, looking at processes of growth and at the living systems of which the organisms - whether botanical, animal or human - were part. It is easy to see why such an approach would have been unpopular with those scientific and commercial interests which stood to gain from applying chemical methods to medicine and food production. ${ }^{47}$

In medicine, a prime reason for the mood of chemical triumphalism was the development of the sulphonamide drugs, whose identification in 1933 by the German scientist Gerhard Domagk, a researcher for the chemical company Bayer, was followed by a succession of breakthroughs during the next twenty years. Whereas doctors in the $1920 \mathrm{~s}$ had relatively few remedies to offer, by the 1950s they had at their disposal in the region of two thousand as one new compound followed another. What need, then, for a scientifically doubtful attempt to seek the laws of health, when dangerous infectious illnesses could be killed off by the silver bullets which the pharmaceutical industry was making available ${ }^{48}$

A speech by the biochemist Professor E. C. Dodds at the seventieth AGM of the Society of Chemical Industry, in July 1951, exemplified the pride with which the industry regarded itself at this time. Dodds outlined 'The Decisive Influence of Chemical Industry

\footnotetext{
${ }^{46}$ Lewis and Brookes, 'A Reassessment', Health and Society, 61, 2 (1983), 336. On the founding and early years of the Soil Association, see Erin Gill, 'Lady Eve Balfour and the British Organic Food and Farming Movement' (unpublished PhD thesis: University of Aberystwyth, 2010), 73-168. For the wider context, see Philip Conford, The Origins of the Organic Movement (Edinburgh: Floris Books, 2001), and The Development of the Organic Network, 1945-1995 (Edinburgh: Floris Books, 2011), 40-70.

47 This parallel between agriculture and human development is explicit in Scott Williamson's Preface to K.E. Barlow, A Home of Their Own (London: Faber and Faber, 1946), 5-7.

${ }^{48}$ Le Fanu op. cit. (note 40), 234-47.
} 
on Medicine', claiming that it was 'entirely helpful and beneficial'; he summarised the advances made possible in therapeutics through aspirin, salvarsan, sulphonamides, antibiotics and, particularly, cortisone; and he rejoiced that certain illnesses, such as pneumonia, had now been relegated to the past. Private enterprise and competition provided the medical practitioner "with that wonderful array of alternatives which today he is privileged to use'. ${ }^{49}$ The chemical industry could, thanks to those advances, claim the moral high ground. It was saving lives, curing serious illnesses and helping to grow increased amounts of crops in a world desperately short of food. To start criticising it, or warning of possible but unproven malign side-effects, ran the risk of appearing inhumane and reactionary.

The Pioneer Health Centre was swimming against a cultural tide, and it would be more than two decades before a critique of the newly dominant medical model emerged through the writings of, among others, Ivan Illich, Thomas McKeown and Ian Kennedy. Kennedy's The Unmasking of Medicine condemned the dominant philosophy of medicine for its emphasis on disease, its military metaphors, its neglect of the idea of the patient as a whole person and its separation of the malady from the patient. Kennedy wrote of the cachet which doctors hoped to gain from being considered scientists, and attacked the baleful influence of teaching hospitals, with their emphasis on technology. One finds GPs expressing similar views in Jonathan Gathorne-Hardy's book Doctors, with their criticism of the exclusively scientific nature of medical training, which occurs in hospitals and gives no idea of the work of GPs or of their patients' lives. ${ }^{50}$ It was with the patients' lives beyond the hospital or the GP's consulting room that Scott Williamson, Pearse and their colleagues were particularly concerned.

\section{Concluding Comments}

The view that the National Health Service was chiefly to blame for the closure of the Pioneer Health Centre ignores the complexity of the circumstances in which the closure occurred. If any one body is responsible, the Medical Research Council appears to have a strong claim; but various factors contributed to the Centre's demise. Scott Williamson sought official recognition for the Centre in order to find the money that he could not raise from the families of Peckham, but his antagonism towards government policy and orthodox science were guaranteed to alienate those whom he approached. Nor could he offer a clear philosophical basis for his radical approach to the study of human biology; his ideas, painstakingly pieced together by Innes Pearse from innumerable notes, were not published until twelve years after he died, as Science, Synthesis and Sanity (1965). This book is regarded as exceptionally difficult to understand even by those favourable to what Scott Williamson had tried to achieve.

Scott Williamson and Pearse wanted to develop a science of ethology (the study of human health) as opposed to the centrality in medicine of pathology (the study of sickness); orthodox medical science, increasingly dominated by pharmaceuticals, technology and statistics, and looking to cure existing illness and disability, was not interested. The Pioneer Health Centre, although describing itself as an 'experiment', did

\footnotetext{
49 Chemistry and Industry, 21 July 1951, 621-23: 623.

${ }^{50}$ Ivan Illich, Limits to Medicine (London: Marion Boyars, 1976); Thomas McKeown, The Role of Medicine (London: Nuffield Provincial Hospitals Trust, 1976); Ian Kennedy, The Unmasking of Medicine (London: Allen and Unwin, 1981), 17-22, 34-36. Jonathan Gathorne-Hardy, Doctors: The Lives and Work of GPs (London: Weidenfeld and Nicolson, 1984), 239.
} 
not meet the criteria being established by the Medical Research Council. Today, though, its work might well be considered to fall within the parameters of the science of epidemiology, which, according to Rodolfo Saracci, explores health and disease in connection with a range of factors, 'from the level of the molecule ... to the level of society ... This broad perspective makes epidemiology at the same time a biomedical and a social science'. Saracci distinguishes between 'observational' and 'experimental' studies or 'intervention'. The latter are dominant in the biomedical sciences. But in the former, 'Epidemiologists observe what happens in a group of people, record health-related events, ask questions, take measurements of the body or on blood specimens, but do not intervene actively in the lives or the environments of the subjects under study.' The PHC's bias in favour of selfselection would still be problematic, though. As the epidemiologist Dr Julian Tudor Hart wrote to Dr Peter Mansfield: 'If we really are human biologists, we need the discipline of facing up to the needs and wishes of genuinely random samples of the population, rather than self-selected volunteers .... I realise that much preventive work must depend on volunteer groups, but the population at risk from which they are drawn must remain very important. ${ }^{51}$ Regrettably, we can never know how the Peckham doctors would have responded to this criticism of their methodology.

${ }^{51}$ Rodolfo Saracci, Epidemiology: A Very Short Introduction (Oxford: Oxford University Press, 2010), 10-11. Letter, Julian Tudor Hart to Peter Mansfield, 30 April 1980; in author's possession. Peter Mansfield, when a young academic medical researcher, was profoundly influenced by the ideas of Dr Innes Pearse; interview with Dr Mansfield, 6/7 November 2008. 